\title{
Rhetoric or action: Are South African municipalities planning for climate change?
}

\author{
Corresponding author \\ Willemien Faling \\ At the time of writing the article: Lecturer, Department of Town and Regional Planning, University of Pretoria, \\ Pretoria \\ Current position: Senior Researcher, CSIR Built Environment \\ CSIR, PO Box 395, Pretoria 0001 - South Africa \\ Tel: $+27(0) 128412553$ (office) \\ Fax: +27 (0)12 8414036 Cell: \\ $+27(0) 824985324$ \\ Email: wfaling@csir.co.za
}

\section{Co-authors:}

Johann WN Tempelhoff

Professor

School of Basic Sciences, North West University, Vaal Triangle Campus

PO Box 1174, Vanderbijlpark 1900 - South Africa

Tel: $+27(0) 169103450$ (office)

Fax: $+27(0) 169103450$ Cell:

$+27(0) 825629510$

Email: Johann.Tempelhoff@,nwu.ac.za

Dewald van Niekerk

Professor

African Centre for Disaster Studies, North West University, Potchefstroom

Private Bag X6001, Potchefstroom 2520 - South Africa

Tel: $+27(0) 182991620$ (office)

Fax: $+27(0) 182935266$ Cell: +27

(0)823385919

Email: Dewald.VanNiekerk@,nwu.ac.za

In 2008 the South African National Disaster Management Centre commissioned a study into measures taken by local municipalities to plan for climate change. Two areas were selected for their dissimilar climatic challenges: the //Khara Hais Municipality, a semi-desert area in the Northern Cape Province plagued by droughts and severe weather events, and the George Municipality, an area in the Western Cape Province plagued by droughts, the rising sea level and flash floods were selected for their dissimilar climatic challenges. It was found that 
despite South African laws and regulations requiring local government to take action to reduce the risk for disasters, planning for climate change mostly remains sophisticated rhetoric in the two municipalities. This lack of urgency can be ascribed to other more pressing developmental priorities in local municipalities. It would, however, be short-sighted of municipalities not to plan for climate change as major setbacks in hard-won economic and social development follow a disaster.

Keywords: climate change adaptation; climate change mitigation; disaster risk reduction; local government

\section{Introduction}

The impact of climate change on human settlements ranges from being insignificant to catastrophic disasters. The increasingly clear prognosis from the United Nations International Strategy for Disaster Reduction (UNISDR) and the Intergovernmental Panel on Climate Change (IPCC) is that hazards and extreme climatic events are increasing in frequency as well as severity (UNISDR, 2010; IPCC, 2007). The consequence is bigger losses more often - particularly for the poor; but also shifts in environmental conditions that are bound to have long-term implications for human settlements - particularly cities in the developing world that are already challenged by a range of socio-economic development stresses (Parnell, et al., 2007 p. 359).

In South Africa, the National Disaster Management Act tasks all spheres of government - in collaboration with civil society - to undertake to protect people, infrastructure and other national assets from the impact of disasters (RSA, 2002). It is therefore the duty of government to plan for climate change adaptation and mitigation to reduce the vulnerability of people, infrastructure and other national assets to climatic change; to protect development gains (Bulkeley \& Betsil, 2005:2); as well as augment social justice by 'reducing the transfer of environmental costs to other people, other ecosystems or into the future' (Satterthwaite, 1997:1669).

Limited research has been conducted to determine what local governments in South Africa are doing to pursue these goals. The South African National Disaster Management Centre therefore commissioned research into the measures taken by local municipalities in 
anticipation of, and in response to climate change (see Van Niekerk et al., 2009). Rutherford et al. (1999) and Midgley et al. (2005) indicated that the Northern and Western Cape provinces are the regions most at risk from future climate change and climate variation in South Africa, therefore two local municipalities in these provinces - George and //Khara Hais - were selected for this study.

George Local Municipality is a coastal area located in the Eden District Municipality in the Western Cape Province, and is plagued by droughts, flash floods and sea storm surges. //Khara Hais Local Municipality is a semi-desert area situated in the Siyanda District Municipality in the Northern Cape Province. The area experiences more frequent severe weather events, such as hail, wind and torrential rain, flash floods, as well as periodical droughts.

\section{Methodology}

For the purpose of the study, the local municipality with its urban and rural areas constitute the unit of analysis since the natural environment and the farming, forestry and mining activities comprise an integral part of the urban economy and social texture of both societies.

A trans-disciplinary research strategy was pursued to locate diverse sources of local climate knowledge. Desktop studies and in-situ interviews were conducted by researchers active in the fields of disaster risk reduction, urban and regional planning, water management, history and public administration. Researchers also observed the impacts of climate changes where

these were visible, e.g. dustbowls in places that were previously under cultivation in the region of //Khara Hais, and sand dunes being eroded away from under beach houses in George Municipality.

Farmers in the rural parts of //Khara Hais were interviewed during the period August 2008 to December 2008 to draw on the memory of population groups who have been resident in the region for generations. The focus of these interviews was on collecting popular memories of past climatic conditions and how the present changes are being interpreted. In the Northern Cape it was possible to collect substantial and detailed personal oral histories of climate change awareness from various farmers in the districts of Gordonia, Upington, the Orange River and Augrabies. In order to comprehend the potential impact of water scarcity on the region, the study area was extended to Rietfontein, near Mier, where local irrigation activities 
have dwindled substantively since the 1980s.

In the case of George, a local resident was identified to have kept records of local drought and flood events from newspaper articles, which then became a qualitative input in the research project. From this compilation of a chronological list of droughts, floods and damage, it was possible to form an impression of changes in the local climate since the 1960s.

In addition various role-players in both municipalities were interviewed in the period August 2008 to February 2009 to gauge if any changes to the climate have been observed and what the perceived impacts on local residents, business, agriculture, tourism and the built environment are. Interviews were conducted with the disaster managers as well as the urban planners of the local and district municipalities; the senior manager for social services in George; an employee of the Western Cape Province; the manager of Santam Insurance in //Khara Hais; the chambers of commerce, urban planning consultants and real estate agents in both cities; a journalist in George; and an accountant in //Khara Hais.

In addition to these interviews, a number of strategic development plans, frameworks and instruments on local ${ }^{1}$, district ${ }^{2}$ and provincial $^{3}$ level were compared with the national disaster risk management legislation and regulations to assess their observance of disaster risk reduction requirements and the extent to which climate change adaptation and mitigation are being anticipated and addressed.

\section{Climate change concerns in South Africa}

\subsection{Climate change projections for South Africa}

The IPCC concludes in its Fourth Assessment Report that all of Africa during all its seasons is projected to warm during the twenty-first century at rates greater than the global annual mean warming (Christensen et al., 2007:866). Future climate scenarios can be obtained for South Africa and its provinces by using ocean atmosphere general circulation model simulations - dynamically downscaled over southern Africa with a regional climate model

\footnotetext{
1 Integrated Development Plans, and Spatial Development Frameworks

2 Integrated Development Plans, Growth and Development Strategies, Spatial Development Frameworks, Local Economic Development strategies, and the State of the Environment Report

3 Climate Change Strategy and Action Plan for the Western Cape Province
} 
(Engelbrecht et al., 2009:1014; Hewitson \& Crane, 2006:1315). Under conditions of double the current natural greenhouse gas (GHG) concentrations it is projected that average temperatures would have risen by two degrees Celsius, and minimum winter temperatures by as much as three degrees Celsius by 2050 in many parts of southern Africa (Christensen et al., 2007:866; Tyson \& Gatebe, 2001:106). The only part of South Africa where an increase in annual rainfall is projected is the central interior, though the eastern parts of South Africa may experience increased summer rainfall (Engelbrecht et al., 2009:1014).

Regional projections relevant to this study anticipate that the Northern Cape will become hotter and drier in future. The latter can be ascribed to the absence of rain cloud belts that normally bring rain to this region in the late summer. These cloud belt formations will be less frequent due to the increase in mid-level high-pressure systems and their subsidence over southern Africa (Engelbrecht et al., 2009). The area will also experience higher average temperatures, and increasingly erratic and reduced water supply from the Orange River as larger population concentrations in urban centres and farming settlements upstream could claim more of the available water supplies (DEAT, 1999).

George is renowned for its high rainfall and temperate climate throughout the year, but research indicates that the region is expected to become significantly drier during winter time with an average rainfall decrease of about 20\%. This is due to a projected southerly movement of cold fronts that bring winter rains to the south and south-western Cape. The strengthening of sub-tropical high-pressure belts over South Africa in the winter may cause this projected future movement, shortening the core winter rain season. Temperatures are expected to rise (Engelbrecht et al., 2009; Engelbrecht, 2005:57-74; Midgley et al., 2005:28,30).

\subsection{Climate change concerns in South Africa}

It is commonly accepted that climate change-related hazards and resulting disasters are on the increase (IFRC \& RCS, 2007). Municipalities in developing countries experience major setbacks in hard-won economic and social development following such events. Governments in general have insufficient capacities to predict, monitor, mitigate and manage hazards and disasters. Limited funds from longer-term development objectives are then typically diverted to short-term emergency relief and reconstruction needs, frustrating efforts aimed at promoting sustainable development (Anderson \& Woodrow, 1998:10-1; Annan, 1999:4,5). 
South Africa faces increasing occurrences of floods, tornadoes and hailstorms, storms, heavy rain and winds, veldt fires, snow, and drought (DPLG, 2006). Urban areas in South Africa are particularly vulnerable to climate change-related disasters where structural poverty, substandard infrastructure and housing, high population densities, economic assets, and commercial and industrial activities are concentrated. Due to rapid urbanisation in South Africa, more and more people have been forced to live on floodplains, unstable hillsides, and sinkhole zones - causing loss of livelihoods, aggravating poverty, and the destruction of productive assets and vital infrastructure (Annan 1999; World Bank 2003: xiv; World Bank 2006). Almost half the population of South Africa is frequently exposed to multiple hazards and live under conditions of chronic vulnerability to hazards (DPLG, 2006; NPU, 2000).

Despite these adverse effects, limited measures have been taken by cities in South Africa to adapt to potential consequences of climate change (Joubert, 2006:31-2). Municipalities should be asking themselves: when, where, to what extent the local climate will change, and how this will affect local residents?

\subsection{Climate change adaptation and mitigation}

Climate change adaptation and mitigation are two distinct processes, though they have bearing on one another (Blanco et al., 2009:156). 'Adapting to climate change entails taking the right measures to reduce the negative effects of climate change (or exploit the positive ones) by making the appropriate adjustments and changes' (UNFCCC, 2007:10). Within climate change policy and related literature, mitigation refers to the reduction of greenhouse gas emissions that are seen as the source of climate change (UNISDR, 2009:19-20).

The manner in which developments are designed and planned will have a significant impact on future GHG emissions, as well as settlements' ability to adapt to potential climate change (Bulkeley \& Betsill, 2005:176). Several negative aspects of development could be mitigated through sustainable development planning. However, even if GHG emissions were to be drastically reduced soon, the earth's climate will continue to warm for some time. Many argue that climate change adaptation is therefore inevitable, though adaptation does not solve the long-term problem of damage and increased costs from continued GHG emissions (Hardy, 2003; Munasinghe \& Swart, 2005). 
Sprawled cities have resulted in functional separation and increased journey distances (Bart, 2009; Belzer \& Autler, 2002; Newman \& Kenworthy, 1996). This again led to the decentralisation and dispersion of other land-uses - typical of South African apartheid and early post-apartheid planning practices (DoH, 2004). Although automobiles offer more freedom in space and time, there are many social, economic and environmental disadvantages to a car-dependant society. Keeping in mind 'it is not sufficient to concentrate on either mitigation or adaptation, but a combination of these results in the most sustainable outcomes' (Laukkonen et al., 2009: 287), the following spatial planning measures to promote compact cities are suggested to mitigate global warming and/or adapt to climate change (Bulkeley \& Betsill, 2005:176-7; Hardy, 2003:187,206):

- Strategic nodes and corridors should be identified where city features are concentrated and high density, mixed land-use developments are clustered - especially those that provide a service to the community. Public transport routes should be developed along corridors, and the needs of pedestrians, cyclists and commuters should be prioritised in transport-orientated developments (TODs) (Banister, 2005; Swilling et al., 2008; Watson et al., 2004). These TODs reduce the need to travel by integrating land-use and public transport, and thus promote walkability, densification, connectivity and sustainability. TODs furthermore protect natural and agricultural landscapes, which could in turn serve as retention ponds when flooding occurs (Bart, 2009; Banister, 2005; Belzer \& Autler 2002; Behrens \& Wilkinson 2003).

- Urban growth edges attempt to contain and locate developments at already prominent activity nodes. It discourages urban sprawl, enables the efficient provision of infrastructure, and ensures optimal use of existing resources (Fraker, 2007; Watson et al., 2004). When key activities are clustered in nodes, it is also easier and more efficient to protect them from the impact of climate change through, for example, the provision of protective infrastructure, than when such activities are dispersed.

- Mixed land-use developments are intended to restructure fragmented, inequitable and inefficient urban forms. Accommodating a diversity of land uses such as residential, commercial and retail in one building or development, afford people the ability to shop, work and play in close proximity to where they live. Mixed land-uses thus reduce the need to travel, and encourage shared infrastructure and facilities (Watson et al., 2004; Eicker, 2009; DoH, 2004; Belzer \& Autler, 2002). This is especially advantageous to 
low-income households or non-profitable land uses that can benefit from the adaptation efforts of others such as shared protective infrastructure.

- Brownfields and vacant sites within the city centre or existing suburbs close to job opportunities and economic activities should be identified for infill development. Close to nodes, households could settle in mixed-use developments, relying on already existing infrastructure (DoH, 2004).

The next section addresses if and how disaster risk management in the form of climate change adaptation is linked to sustainable development planning in the South African legal framework.

\subsection{Institutional framework for urban disaster risk management in South Africa}

There is wide consensus amongst scientists that challenges of climate change, sustainable development and disaster risk must be addressed in an integrated manner (Brooks, 2003:17; Dayton-Johnson, 2004:46; Schipper \& Pelling, 2006:19-38; Carmin et al., 2009). Within South African local government, this integration must be obtained through the medium to long-term development plans of municipalities (Van Niekerk, 2006:96), such as the Integrated Development Plan (IDP), Spatial Development Framework (SDF) and Growth and Development Strategy (GDS).

The National Disaster Management Act (RSA, 2002) and the National Disaster Management Framework (RSA, 2005) give priority to developmental measures such as basic public works, effective municipal services and effective spatial planning to reduce the vulnerability of disaster-prone areas, and communities and households at risk. They stipulate the following concerning development planning in local governments in South Africa:

- Local disaster risk management centres must assess the vulnerabilities of communities and households to hazards that could result in a disaster. They must prevent or reduce the risk of disaster by the integration of prevention and mitigation methodologies within development plans, programmes and initiatives. They must also manage high risk developments (RSA, 2002);

- Disaster risk management plans must form an integral part of municipal integrated development processes and plans, and anticipate the types of hazards and disasters that 
are likely to occur (RSA, 2002; RSA, 2005);

- Spatial development frameworks should reflect and monitor hazard and vulnerability factors and ensure relevant spatial information informs disaster risk reduction planning (RSA, 2005);

- Relevant organs of state must execute systematic disaster risk assessments as an integral part of the planning phase for large-scale housing, infrastructure or commercial and industrial development. They must ensure that development initiatives maximise their vulnerability reduction outcomes of disaster-prone areas, communities and households (RSA, 2005);

However, Faling (2008) found that these disaster risk reduction sentiments are not reflected to the same degree of gravity in spatial development planning-related policy and legislation, and climate change is only mentioned in some policies. It therefore seems that disaster risk reduction and climate change are some of the most underestimated issues on the national agenda for development planning. This is mirrored by provincial and local development planning strategies. Studies by Ferreira \& Fritz (2009), Basson \& Horak (2009), Pewa (2009), Dlamini (2009) and Van Wyk \& Delport (2008) have found that the only province in South Africa with a climate change strategy is the Western Cape Province, and the coastal cities of eThekwini and Cape Town are the only metropolitan cities with climate change strategies.

\subsection{Barriers to climate change adaptation and mitigation in South Africa}

There are many challenges that cities in the developing world face when it comes to addressing climate change. Climate change strategies should be integrated with broader sustainable development efforts, but they are often addressed in isolation (Munasinghe \& Swart, 2005; Hardy, 2003). According to Roberts (2008:523) and Halsnæs \& Verhagen (2007:666) this is due to a tension in local governments between the need to provide in the pressing socio-economic development priorities and the need to introduce environmental concerns - which are often severe, but perceived as being less significant - into planning processes. Thus, in many developing countries where the day-to-day needs of people are scarcely being met, issues of sustainable development are but momentary and difficult to reconcile. 
Another barrier to action is that officials in local municipalities do not have a meaningful understanding of the climate change science and the implications of climate change at a local level. Given their workload, they are not likely to have the time to develop this understanding. Municipalities might also face more pressing environmental problems than climate change (though they might be interrelated). Other challenges include the allocation of dedicated human and financial resources to climate change issues, inability to adapt technologically to climate change, the incorporation of climate change considerations into political and administrative decision making, and not having a political champion to drive the climate change programme (Roberts, 2008:525-527).

\section{Planning for climate change: two South African case studies}

This section investigates how two local municipalities in South Africa - faced with diverse but challenging climates - fare in anticipating and planning for climate change.

\section{1//Khara Hais Local Municipality}

\subsubsection{Socio-economic profile}

//Khara Hais is centrally situated in the Northern Cape Province of South Africa - by far the largest province in South Africa. The province is a unique semi-desert area with exceptional natural and cultural attractions. However, due to its aridity, it has the smallest population and thus low densities. It also has the smallest local economy in the country, in which agriculture,

mining, local commerce and tourism count as the most significant economic sectors. Only $25 \%$ of the population in //Khara Hais is economically active - mostly in the agricultural sector. The income distribution remains skewed, and socio-economic pressures such as poverty, poor skills, unemployment, and HIV/AIDS, further add to the development constraints in the municipality (//Khara Hais Local Municipality, 2007; 2008; Siyanda District Municipality, 2007; 2008).

\section{Siyanda District Municipality including the //Khara Hais Local Municipality} (Wikipedia, 2010b)

The //Khara Hais municipal area includes extensive stock farms; a narrow strip of intensive irrigation farming-settlements about 15 to 20 kilometres apart on both sides of the Orange River; and the city of Upington (founded in 1871 as a mission settlement) that serves a regional function (//Khara Hais Local Municipality, 2007; 2008; Raper \& Ball, 2004:387). 
Figure 1 - Location of the Siyanda District Municipality in the Northern Cape

\section{Province}

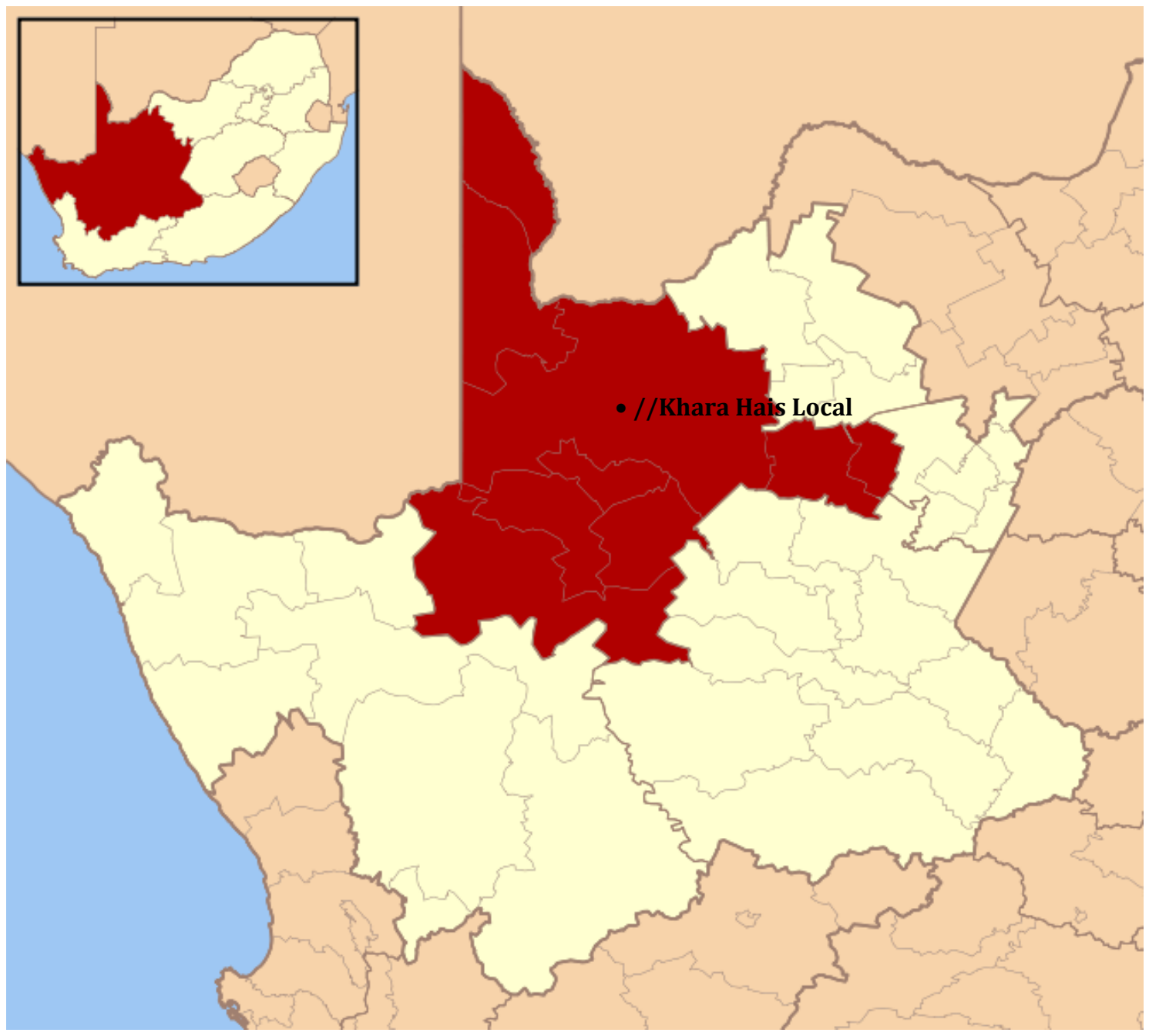

(Wikipedia, 2010b)

\subsubsection{Pressure on the environment}

//Khara Hais is renowned for its hot average daytime temperature and semi-arid climate. The abundant water supply from the Orange River passing through the city of Upington is the lifeline of the economy, agriculture, urban development, tourism, and fauna and flora. However, //Khara Hais is periodically threatened by prolonged droughts that are often terminated by severe floods. Intense rainfall contributes to the vulnerability of the area, resulting in erosion, instability in the vegetation and a decrease in the biodiversity (Oosthuizen \& John, 2005). In addition, the water quality has systematically degraded over time because of growing agricultural and industrial activities upstream from Upington 
(//Khara Hais Local Municipality, 2008; Siyanda District Municipality, 2008).

Agricultural activities in the //Khara Hais area include date, raisin and wine farms on the banks of the Orange River. According to the IDP manager of the Siyanda District Municipality some local farmers believe the Orange River will not cease to provide for the demand for water in this semi-desert area. Consequently, they tend to utilise fertile land on the floodplains in an injudicious manner. According to some farmers in the district, this has caused land to become brackish, resulting in expensive rehabilitation of land, the deterioration of the water quality, and an increase in pests and weeds. Further away from the river, extensive cattle farming frequently over-exploit groundwater resources. Some farms exceed the carrying capacity of their land, causing overgrazing, alien plant species to invade, a decrease in carrying capacity of the land and its bio-diversity, and an increase in erosion (Meyer, 2001).

Tourist activities also negatively impact on the environment through land and water pollution, fires, destruction of the unique fauna and flora that causes a loss in biodiversity, damage to ecosystems, deterioration of gravel roads, and erosion (//Khara Hais Local Municipality, 2008; Siyanda District Municipality, 2008).

\subsubsection{Observations on climatic change and its impact}

Thirty-one residents, farmers, businesses and officials in the local and district municipalities of //Khara Hais and Siyanda were interviewed during the course of the research project to record what, if any, changes to the climate they have observed. All were conscious of changes in the climate. The farmers have noted the weather becoming more erratic and the seasons taking on different characteristics - for example summer starts later in the year and has become hotter and drier with high intensity rainfall. Hailstorms, uncommon for this area, are causing extensive damage, especially to harvests. Townspeople have noticed periodic, intense rainfall and strong wind gusts unlike a decade ago in Upington. Whenever this occurs, the 'new shopping mall' is partly flooded, as the stormwater infrastructure cannot accommodate the run-off.

Farmers usually have one to three days' warning to remove pumps and other equipment when heavy rainfall upstream causes the Orange River to flood, but they often still sustain massive losses. If it rains too often during summer, the grapes and dates cannot dry. Farmers therefore 
find it difficult to plan their harvests. In comparison, if the weather is to become hotter and drier - as research indicates - cattle farming would become near unfeasible.

The disaster manager (personal communication, James de Monk, Disaster Manager, //Khara Hais Local Municipality, South Africa, 1 December 2008) was concerned about the poor and the unskilled who are most vulnerable to climatic changes. Informal settlements and former black townships in the urban areas are relentlessly hit by severe weather events. The urban planners ascribe this to roads that are not tarred, substandard building material, poor construction methods, and inadequate stormwater provision. The disaster risk manager fears that unskilled labourers might flee farms and rural towns when water or employment opportunities on farms and in the smaller towns become scarce. Planners are concerned that these climate migrants may seek security of tenure and access to basic municipal services, schools and clinics in Upington - adding pressure to the already existing backlog on service provision with many negative direct and indirect consequences for the district.

Climate change can further lead to significant financial losses. This will not only have a direct impact on the agricultural sector of the district, but can also have further repercussions for the greater Northern Cape Province. During 2008, R37 million was needed in drought relief due to the impact of climate variation in the Northern Cape Province (Thomas 2008).

\subsubsection{Planning for climate change adaptation and mitigation}

The climate of //Khara Hais is changing and impacting all aspects of life, which should cause local and district councils to plan for these challenges through spatial planning, land-use management, disaster risk reduction, local economic development, and municipal service provision. However, an assessment of the strategic planning documentation of //Khara Hais Local Municipality and Siyanda District Municipality during the course of the project shows that there had been no analysis of the present or future expected impacts of climate change in the district, and no policies or directives dealing proactively with climate change. There was also no council resolution to decrease its own GHG emissions.

Many studies (Bulkeley \& Betsill, 2005; Carmin et al., 2009; Halsnæs \& Verhagen, 2009) propose sustainable development as an effective way to mitigate global warming and adapt to climate change. In several of the strategic planning documentation such as the Siyanda Growth and Development Strategy (2008), the //Khara Hais Integrated Development Plan 
(2007), Spatial Development Framework (SDF) of 2008, and disaster risk management plans, sustainability is encouraged for all future developments in the district. Yet only the //Khara Hais SDF attempts to define sustainable development, what it entails, and measures to attain sustainability. One has to conclude that sustainable development remains sophisticated rhetoric, with no concrete implementation strategy.

\subsection{George Local Municipality}

\subsubsection{Socio-economic profile}

The George Local Municipality is situated halfway between Cape Town and Port Elizabeth in the Western Cape Province, well-located in relation to the district and the Garden Route. It lies between the Outeniqua Mountains and the Indian Ocean, 200 metres above sea level. The city of George was founded in 1812 under the British administration and became a major administrative centre in the southern Cape. The municipal area includes the City of George (including Pacaltsdorp and Thembalethu), the towns of Wilderness and Harold's Bay, coastal resorts such as Victoria Bay and Kleinkrantz, productive land for agriculture and forestry, pristine national parks, indigenously vegetated areas, and unspoilt coastline (George Local Municipality, 2007b; 2008a).

\section{Eden District Municipality including the George Local Municipality}

(Wikipedia, 2010a)

The George economy is well balanced and diversified, rooted in agriculture, manufacturing, tourism, trade and business. As the business and economic hub of the Southern Cape, George has considerable growth prospects, which strongly relate to the natural resource endowment of the municipal area. Agriculture is a major land-use in the municipal area outside the City of George, covering a large percentage of its land (George Local Municipality, 2007a; Eden District Municipality, 2006).

Like elsewhere in South Africa, the lowest income groups in George reside furthest from job opportunities. Unemployment and poverty are major social issues and the George economy is not able to absorb the many unskilled migrants from the Eastern Cape making their home in George (George Local Municipality, 2008a; Eden District Municipality, 2006). 
Figure 2 - Location of the Eden District Municipality in the Western Cape Province

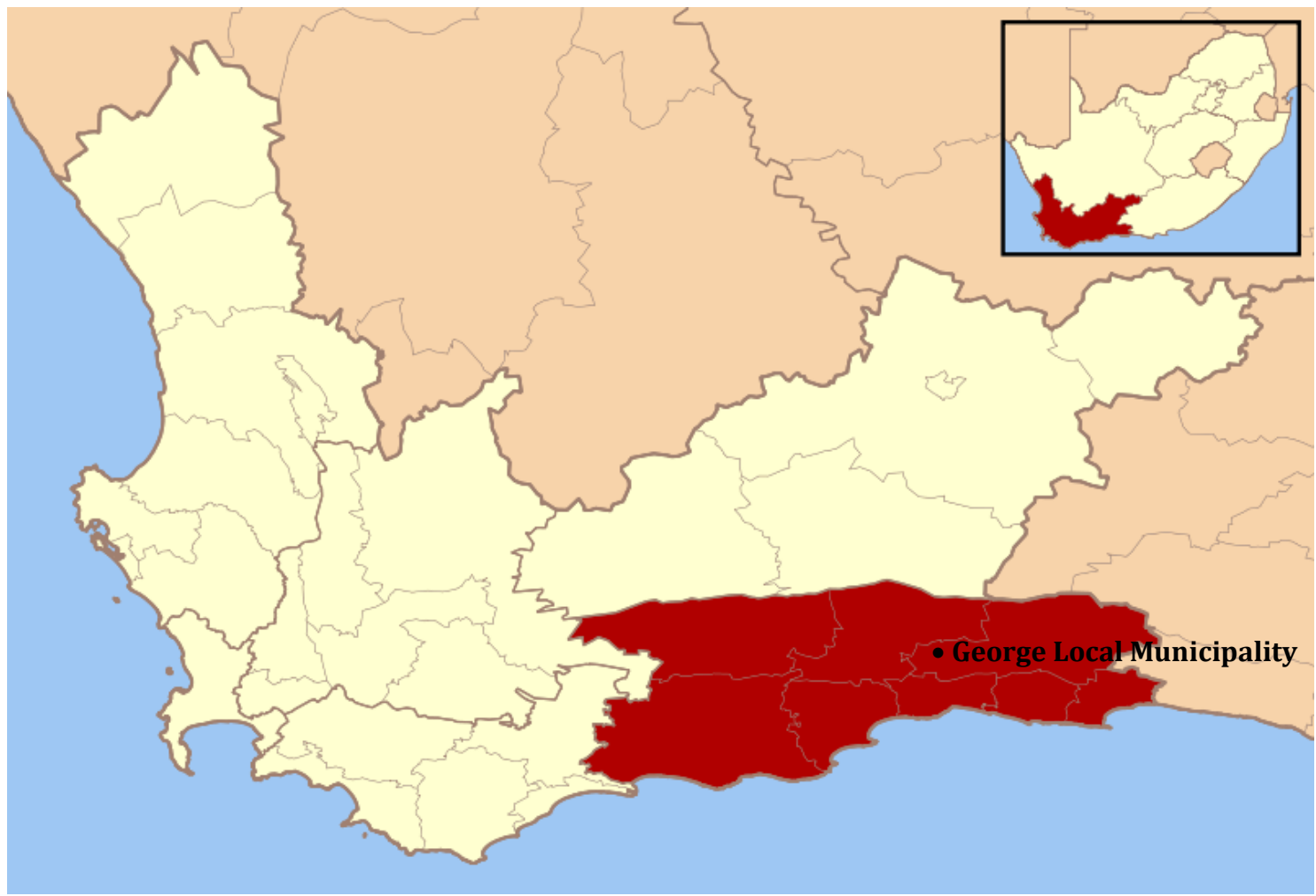

(Wikipedia 2010a)

\subsubsection{Pressure on the environment}

The George economy was traditionally based on forestry and agriculture. Over time, commercial forests were established on large areas cleared of natural vegetation, resulting in a transformation of the natural environment that protected the steep slopes of river gorges. Vegetation within George forms an important part of the Cape Floral Kingdom - one of the richest floras in the world. The natural vegetation is threatened by the reduction in water quality and quantity, pollution and eutrophication, the introduction of invasive alien species, agricultural activities and urban expansion. Conversely, forestry and agriculture are threatened by urban expansion onto scarce, high potential remaining farmland; the development of golf estates; the provision of land for small farmers; and an increase in the demand for water. Water consumption in George has increased to the extent that the demand for water exceeds the availability (George Local Municipality, 2007b; 2008b).

Many urban developments have been established along the coastal zone, causing increased 
pollution through sewage and effluents released into the marine environment. These developments have a destabilising effect on the environment, disrupt natural drainage systems, and cause run-off to become unstoppable, resulting in heavy losses of property and infrastructure. Economic, industrial and commercial activities also negatively affect the environment by changes in land-use, and increased production and release of wastes. In addition, tourism has augmented the number of recreational activities on the estuaries and the coastline, mounting the pressure on resources in the coastal zone (George Local Municipality, 2007b; 2008b; Eden District Municipality, 2008b).

\subsubsection{Observations on climatic change and its impact}

It seems climatic changes have a more pronounced impact on life in George than in //Khara Hais. Residents, businesses, farmers and local and district government officials are quite concerned about the phenomenon. Townspeople have observed longer periods of drought during winter (which is the rainy season) combined with bursts of torrential rainfall - to the extent that they experience 'green droughts' (on the surface it looks green, but there is a general lack of water).

An official of the Western Cape Province (personal communication, Dawie de Villiers, Western Cape Provincial Department of Agriculture, George, South Africa, 3 December 2008) has noticed that every successive flash flood increases in intensity, and the natural environment does not recover from the damage in time to face the next severe weather event. The many ravines and built-up areas contribute to channelling the strong run-off and flash floods after heavy downpours. This increased intensity in precipitation and resultant increase in run-off cause landslides, erode riverbanks, and damage irrigation infrastructure. Unlike //Khara Hais, an early warning system in George is not as effective, as it is but ten kilometres from the watershed to the sea down numerous valleys. River-mouths, coastal towns and farms in the district are therefore very vulnerable to flash floods.

A few people described that in 2006 severe weather events and spring-tide occurred simultaneously that resulted in George, Wilderness and quite a few outlying farms being cutoff from each other due to the collapse of several roads and the Kaaimans Bridge between George and Wilderness. George was also cut-off from Oudsthoorn due to rockslides in the Outeniqua Pass. The water supply to some towns collapsed, stormwater pipes burst, streets and houses in the coastal towns of Victoria and Harold's Bay flooded, and sand dunes were 
being washed away from under houses in Wilderness. According to a planner at the Eden District Council, the district has experienced five major disasters in the coastal areas in seven years.

Losses associated with these climatic events are high. In the southern Cape, regional damage estimates amount to more than R2 billion due to severe weather events and flooding between 2003 and 2008 (see Table 1).

Table 1: Damage estimation of climatic events in the southern Cape region (2003-2008)

\begin{tabular}{|c|c|c|c|r|}
\hline Year & $\begin{array}{c}\text { Date } \\
\text { commenced }\end{array}$ & Duration & $\begin{array}{r}\text { Precipitation } \\
\mathbf{( m m )}\end{array}$ & $\begin{array}{r}\text { Damage estimation } \\
\text { (ZAR) }\end{array}$ \\
\hline 2003 & 24 March & 2 days & 287 & $\begin{array}{r}\text { R250 000 000 } \\
\text { (combined) }\end{array}$ \\
\hline 2003 & 10 May & 2 hours & 73 & $\begin{array}{r}\text { R23 000 000 } \\
\text { (combined) }\end{array}$ \\
\hline 2004 & 22 December & 45 min & 243 & R712 000 000 \\
\hline 2005 & 14 January & 90 min & 90 & R1 069 000 000 \\
\hline 2006 & 1 August & 3 days & 378 & R8 000 000 \\
\hline 2007 & 22 November & 3 days & 539 & -- \\
\hline $2008 *$ & -- & -- & & R2.062 billion \\
\hline
\end{tabular}

*Data for 2008 is incomplete.

(Holloway, 2007; Western Cape Provincial Gazette, 2005; Steyn, 2008; Verslagspan, 2008).

The most vulnerable people to climate change in George are poor people who often settle in informal settlements on floodplains or hillsides. George is also a safe-haven for many people from other parts of the country. People flee crime in the metropolitan cities and relocate to George. People from landlocked provinces own holiday homes in the district, others flee the Karoo droughts, or retire in George. According to the Chamber of Business, many local and international tourists come to Glentana, Victoria Bay and Harold's Bay, but return home or leave for other parts of the country if it rains heavily during the holiday seasons. This has a huge impact on businesses in the tourist industry. 


\subsubsection{Planning for climate change adaptation and mitigation}

Though the threat of climate change is mentioned in a number of local strategies, it is only to the extent that it is identified as a threat to the area, offering no measures to adapt to climate change. Sustainable development is advocated and promoted in many documents such as the Eden District Municipality’s GDS (2007), IDP (2008a), and SDF (2003), as well as the George Local Municipality SDF (2007b, 2008a \& 2008b). However, the local municipality is so overwhelmed with attempting to provide for the basic needs of people and creating decent living environments for the poor, that climate change is not a priority.

The Western Cape Provincial Government has conducted a vulnerability and adaptation assessment of the effects of climate change on the Province (Midgley et al., 2005). The Western Cape Provincial Government (2008) developed a comprehensive climate change strategy and action plan (the first regional climate change adaptation and mitigation strategy in Africa). To accomplish the objectives of the strategy throughout the province, this strategy needs to be translated into local strategies and efforts, which, at the time of writing this article, has not yet been achieved.

Given the significance of global warming and climate change, sustainable development measures that specifically integrate mitigation and adaptation measures are needed in development planning. Furthermore, concrete action plans identifying localities, allocating budgets and identifying responsible people are needed.

\section{Conclusion}

Though national legislation and regulations require the integration of disaster prevention and mitigation methodologies within development plans and frameworks, and though people are concerned about climate change's impacts on business, agriculture, tourism and the built environment in both //Khara Hais and George local municipalities, this study found that climate change is not specifically addressed in any of the strategic development planning documentation to assist in building resilience to climate change impacts at the local level. Sustainable development is advocated in many of the documents, but no link is made to climate change adaptation and mitigation. It is concluded that disaster risk reduction in general, and climate change specifically, remains sophisticated rhetoric not yet institutionalised within the practice of decision-making in the two South African local municipalities of George and //Khara Hais. This is probably true of most local municipalities 
in the developing world, and could be ascribed to the seemingly more pressing day-to-day housing, education, services and health needs of people that are scarcely being met. However, it would be short-sighted of municipalities not to plan for climate change as major setbacks in hard-won economic and social development follow a disaster, and scarce funds from longerterm development objectives are diverted to short-term emergency relief and reconstruction.

There are, however, some exceptions. Cape Town has already implemented a number of sustainable coastal management plans as part of their Coastal Zone Management Strategy. Apart from an urban growth edge, it also has a coastal edge. A climate change adaptation plan is in the making that will include a framework of action (personal communication, Gregg Oelofse, Head: Environmental Policy and Strategy, City of Cape Town, South Africa, 5 February 2010). The city has furthermore developed a storm surge model, to determine areas at risk, and to assist in deciding whether to follow a strategy of managed retreat, building coastal defences, extending the beach area, or a combination of these strategies for coastal protection zones.

More mitigation than adaptation examples are available, but a few cities in developing countries are also concentrating on adaptation. Examples include: the City of Durban with its Climatic Future for Durban and Headline Adaptation Strategy (Carmin et al., 2009:6-9); Quito in Ecuador formalised a climate change strategy in 2008 (Carmin et al., 2009:14); Dhaka in Bangladesh combined its strategic framework and a locally-informed model of sustainable development (Roy 2009:276); and various coastal cities in China plan for the effect of a rising sea level (Pewa, 2009: 25).

In conclusion, to adequately plan for climate change interventions at various levels of government and civil society are necessary. It remains challenging to budget for an item such as ‘climate change adaptation'. Research by Visser \& Van Niekerk (2009) indicates that to budget for mitigation and adaptation costs, organs of state must use the current funding mechanisms. Other recommendations for local government to plan for climate change include: 1) translating national and international disaster risk reduction requirements into local initiatives with a concrete agenda and budget allocation for implementation; 2) conducting local disaster risk assessments to determine the present and future threats from climate change, and formulating specific, contextualised adaptation strategies to be integrated with the strategic development plans; 3) introducing land-use management measures that 
strive to reduce the vulnerabilities of poor communities, and ensure resilient buildings and infrastructure that can maintain essential services when extreme events associated with climate change occur; 4) monitoring and reporting on climate change initiatives, to prevent it being pushed from the agenda by more pressing developmental issues; 5) reducing local government's operational impact on the environment; and 6) promoting the implementation of greener technologies in all future development planning.

\section{Acknowledgements}

This paper draws on research funded by the South African National Disaster Management Centre. The authors would like to thank the anonymous reviewers for their valuable comments on the drafts of the article.

\section{References}

Anderson, MB \& Woodrow, PJ, 1998. Rising from the Ashes: Development Strategies in Times of Disaster. Lynne Rienner Publishers, Boulder.

Annan, KA, 1999. Preventing War and Disaster: A Growing Global Challenge. United Nations, New York.

Banister, D, 2005. Unsustainable Transport: City Transport in the New Century. Taylor Francis group, New York.

Bart, IL, 2009. Urban sprawl and climate change: A statistical exploration of cause and effect with policy options of the EU. Land Use Policy (27)2, 283-92.

Basson, M \& Horak, T, 2009. Reponses to the challenges of climate change by South African cities: The cases of Johannesburg and Tshwane. BT\&RP dissertation, University of Pretoria, South Africa.

Behrens, R \& Wilkinson, P, 2003. Housing and urban transport policy and planning in South African cities: A problematic relationship? In Harrison, P, Huchzermeyer, M \& Mayekiso, M (Eds), Confronting Fragmentation: Housing and Urban Development in a Democratising Society. University of Cape Town Press, Cape Town.

Belzer, D \& Autler, G, 2002. Transit oriented development: Moving from rhetoric to reality. A discussion paper prepared for the Brookings Institution Center on Urban and Metropolitan Policy and the Great American Station Foundation, June.

Blanco, H, Alberti, A, Forsyth, A, Krizek, KJ, Rondríguez, DA, Talen, E \& Ellis, C, 2009. Hot, congested, crowded and diverse: Emerging research agendas in planning. Progress in Planning 71, 153-205.

Brooks, N, 2003. Vulnerability, risk and adaptation: A conceptual framework. Tyndall Centre 
Working Paper No. 38. Tyndall Centre for Climate Change Research and Centre for Social and Economic Research on the Global Environment (CSERGE), School of Environmental Sciences, University of East Anglia, United Kingdom.

Bulkeley, H \& Betsill, MM, 2005. Cities and Climate Change: Urban Sustainability and Global Environmental Governance. Routledge, Oxon.

Carmin, J, Roberts, D \& Anguelovski, I, 2009. Planning climate resilient cities: early lessons from early adapters. World Bank 5th Urban Research Symposium, June, Marseille, France.

Christensen, JH, Hewitson, B, Busuioc, A, Chen, A, Gao, X, Held, I, Jones, R, Kolli, RK, Kwon, W-T, Laprise, R, Rueda, VM, Mearns, L, Menéndez, CG, Räisänen, J, Rinke, A, Sarr, A \& Whetton, P, 2007. Regional climate projections. In Solomon S, Qin, D, Manning, M, Chen, Z, Marquis, M, Averyt, KB, Tignor, M \& Miller HL (Eds), Climate Change 2007: The Physical Science Basis. Contribution of Working Group I to the Fourth Assessment Report of the Intergovernmental Panel on Climate Change. Cambridge University Press, Cambridge.

Dayton-Johnson, J, 2004. Natural disasters and adaptive capacity. Working Paper No. 237. OECD Development Centre, Paris.

DEAT (Department of Environmental Affairs and Tourism), 1999. State of the Environment South Africa: Terrestrial Ecosystems: Impact Part 2. Government Printer, Pretoria.

Dlamini, ZV, 2009. Measures, policies or plans that the City of Tshwane and the City of Cape Town have towards climate change adaption and mitigation. BT\&RP dissertation, University of Pretoria, South Africa.

DoH (Department of Housing), 2004. Breaking New Ground: A Comprehensive Plan for the Development of Sustainable Human Settlement. Government Printer, Pretoria.

DPLG (Department of Provincial and Local Government), 2006. Pilot Study on the Socioeconomic Impacts of Disasters, South-Africa: 1994-2004. Government Printer, Pretoria.

Eden District Municipality, 2003. Spatial Development Framework.

Eden District Municipality, 2006. Local Economic Development Fact Sheet No. 1.

Eden District Municipality, 2007. Growth and Development Strategy: Eden Local Economic

Development Strategy. Eden Growth and Development Summit, 24 November, George.

Eden District Municipality, 2008a. Revised Integrated Development Plan: 2008/2009.

Eden District Municipality, 2008b. State of the Environment Report.

Eicker, K, 2009. Sustainable architecture can be done. Urban Green File (13)6, 10-7.

Engelbrecht, FA, 2005. Simulations of climate and climate change over southern and tropical 
Africa with the conformal-cubic atmospheric model. In Schulze, RE (Ed.) Climate Change and Water Resources in Southern Africa: Studies on Scenarios, Impacts, Vulnerabilities and Adaptation. Report 1430/1/05. Water Research Commission, Pretoria.

Engelbrecht, FA, McGregor, JL \& Engelbrecht, CJ, 2009. Dynamics of the conformal-cubic atmospheric model projected climate-change signal over southern Africa. International Journal of Climatology 29, 1013-33.

Faling, CW, 2008. Vulnerability to disaster impacts: One of the most underestimated issues in urban development? Planning Africa Conference, 14-16 April 2008, Johannesburg, South Africa.

Ferreira, MAW \& Fritz, C, 2009. To what extent are development plans in South Africa aimed at reducing vulnerabilities given the threat of climate change? BT\&RP dissertation, University of Pretoria, South Africa.

Fraker, H, 2007. Where is the urban design discourse? EDRA/Places Awards (19)3, 61-3.

George Local Municipality, 2007a. Integrated Development Plan: 2007-2011.

George Local Municipality, 2007b. Spatial Development Framework Vol III: Urban Structure Framework.

George Local Municipality, 2008a. Spatial Development Framework Vol I: Main Report, Jan 2008 draft 2.

George Local Municipality, 2008b. Spatial Development Framework Vol II: Strategic Environmental Assessment.

Halsnæs, K \& Verhagen, J, 2007. Development based climate change adaptation and mitigation - conceptual issues and lessons learned in studies in developing countries. Mitigation and Adaptation Strategies for Global Change 12, 665-84.

Hardy, JT, 2003. Climate Change: Causes, Effects and Solutions. John Wiley and Sons, Chichester.

Hewitson, BC \& Crane, RG, 2006. Consensus between GCM climate change projections with empirical downscaling: precipitation downscaling over South Africa. International Journal of Climatology 26, 1315-1337.

Holloway, A, 2007. Background, conceptual framework and methodology. Severe Weather Compound Disaster: August 2006 Cut-off lows and their Consequences in the Southern Cape. Cape Town, South Africa.

IFRC \& RCS (International Federation of Red Cross and Red Crescent Societies). 2007. World Disasters Report 2007. http://www.ifrc.org/publicat/wdr2007 Accessed 23 August $\underline{2008 .}$. 
IPCC, 2007. Climate Change 2007: Synthesis Report. Contribution of Working Groups I, II and III to the Fourth Assessment Report of the Intergovernmental Panel on Climate Change. [Core Writing Team, Pachauri, R.K and Reisinger, A. (eds.)]. Geneva: Intergovernmental Panel for Climate Change (IPCC).

Joubert, LS, 2006. Scorched: South Africa’s Changing Climate. Wits University Press, Johannesburg.

//Khara Hais Local Municipality, 2007. Five Year Integrated Development Plan (IDP): 20072012.

//Khara Hais Local Municipality, 2008. Spatial Development Framework. Vol I-III.

Laukkonen, J, Blanco, P, Lenhart, J, Keiner, M, Cavric, B, \& Kinuthia-Njenga, C, 2009. Combining climate change adaptation and mitigation measures at the local level. Habitat International 33, 287-292.

Meyer, S. 2001. 'n Omgewingsentrum as omgewingsbestuursinisiatief vir die Noord-Kaap Provinsie, Masters dissertation, Randse Afrikaanse Universiteit, South Africa. http://etd.rau.ac.za/theses/available/etd0509200515715/restricted/Hoofstuk3'nOmgewings entrumteUpington.pdf Accessed 25 Nov 2008.

Midgley, GF, Chapman, RA, Hewitson, B, Johnston, P, De Wit, M, Ziervogel, G, Mukheibir, P, Van Niekerk, L, Tadross, M, Van Wilgen, BW, Kgope, B, Morant, PD, Theron, A, Scholes, RJ \& Forsyth, GG, 2005. A status quo, vulnerability and adaptation assessment of the physical and socio-economic effects of climate change in die Western Cape. Report to the Western Cape Government. CSIR Report no. ENV/-S-C 2005-073. CSIR Environmentek, Stellenbosch.

Munasinghe, M \& Swart, R, 2005. Primer on Climate Change and Sustainable Development: Facts, Policy Analysis and Applications. Cambridge University Press, Cambridge. municipalities in South Africa. National Disaster Management Centre, Pretoria.

Newman, PWG \& Kenworthy, JR, 1996. The land use-transport connection: An overview. Land Use Policy (13)1, 1-22.

NPU (National Population Unit), 2000. The State of South Africa’s Population Report 2000: Population, Poverty and Vulnerability. Department of Social Development. Government Printer, Pretoria.

Oosthuizen, R \& John, J, 2005. Northern Cape: State of the Environment Report Atmosphere and Climatic Specialist Report. CSIR, Pretoria.

Parnell, S, Simon, D, \& Vogel, C, 2007. Global environmental change: conceptualising the growing challenge for cities in poor countries. Area (39)2, 357-369. 
Pewa, NA, 2009. Reducing the risk for disaster through climate change adaption and mitigation strategies in the City of eThekwini. BT\&RP dissertation, University of Pretoria, South Africa.

Raper, PE \& Ball, J, 2004. South African Place Names. Jonathan Ball Publishers, Cape Town.

Roberts, D, 2008. Thinking globally, acting locally - institutionalizing climate change at the local government level in Durban, South Africa. Environment \& Urbanization (20)2, 521537.

Roy, M, (2009). Planning for sustainable urbanisation in fast growing cities: Mitigation and adaptation issues addressed in Dhaka, Bangladesh. Habitat International 33, 276-286.

RSA (Republic of South Africa), 2002. Disaster Management Act, No. 57 of 2002. Government Printers, Pretoria.

RSA (Republic of South Africa), 2005. National Disaster Management Framework. Government Printers, Pretoria.

Rutherford, MC, Midgley, GF, Bond, WJ, Powrie, LW, Roberts, R \& Allsopp, J, 1999. South African country study on climate change: Plant biodiversity, vulnerability and adaptation assessment. National Botanical Institute, Cape Town. http://www.environment.gov.za/ClimateChange2005/Vulnerability\%20and\%20Adaptation \%20Sector\%20Reports/Plant\%20Biodiversity/biodiversity.pdf Accessed 2 March 2010.

Satterthwaite, D, 1997. Sustainable cities or cities that contribute to sustainable development. Urban Studies 34(10), 1667-91.

Schipper, L \& Pelling, M, 2006. Disaster risk, climate change and international development: scope for, and challenges to, integration. Disasters 30(1), 19-38.

Siyanda District Municipality, 2007. Five Year Integrated Development Plan (IDP): 2007/8 2011/12.

Siyanda District Municipality, 2008. Growth and Development Strategy.

State of the Environment Report. Workshop 1: Identification of environmental issues.

Steyn, T, 2008. Eden dalk tot rampgebied verklaar. Die Burger, Jan. 17.

Swilling, M, De Wit, M \& Thompson-Smeddle, L, 2008. You the urban planner. In Zipplies, R (Ed.), Bending the Curve: Your Guide to Tackling Climate Change in South Africa. Africa Geographic, Cape Town.

Thomas, B, 2008. Reclassifying drought in South Africa. http://carbon-basedghg.blogspot.com/2008/09/reclassifying-drought-in-south-africa.html Accessed on 3 March 2010. 
Tyson, PD \& Gatebe, CK, 2001. The atmosphere, aerosols, trace gases and biogeochemical change in southern Africa: A regional integration. South African Journal of Science 97(3/4), 106-18.

UNFCCC (United Nations Framework Convention on Climate Change), 2007. Climate Change: Impacts, Vulnerabilities, and Adaptation in Developing Countries. UNFCCC, Bonn.

UNISDR, 2009. Terminology on Disaster Risk Reduction. Geneva: United Nations International Strategy for Disaster Reduction (UNISDR).

UNISDR, 2010. Local Governments and Disaster Risk Reduction: Good Practices and Lessons Learnt. Geneva: United Nations International Strategy for Disaster Reduction (UNISDR).

Van Niekerk, D, 2006. Disaster Risk Management in South Africa: The function and the activity - towards an integrated approach. Politeia 25(2), 95-115.

Van Niekerk, D, Tempelhoff, JWN, Faling, CW, Thomson, L, Jordaan, D, Coetsee, C \& Maartens, Y, 2009. The effects of climate change in two flood laden and drought stricken areas in South Africa: Responses to climate change - past, present and future. Report to the National Disaster Management Centre. African Centre for Disaster Studies, Potchefstroom.

Van Wyk, MW \& Delport, T, 2008. South Africa's six metropolitan policies and plans for disaster risk reduction. BT\&RP dissertation, University of Pretoria, South Africa.

Verslagspan, 2008. Vloede: Kry rampfonds gereed. Die Burger, Nov. 17.

Visser, R \& Van Niekerk, D, 2009. A funding model for disaster risk reduction in municipalities in South Africa. National Disaster Management Centre, Pretoria.

Watson, D, Plattus, A \& Shibley, R, 2004. Time-saver standards for urban design. Digital Engineering Library @ McGraw-Hill.

Western Cape Province, 2008. A Climate Change Strategy and Action Plan for the Western Cape. Department of Environmental Affairs and Development Planning, Cape Town.

Western Cape Provincial Gazette, 2005. Disaster debriefing December 2004 cut-off low.

Wikipedia, 2010a. Eden District Municipality. http://en.wikipedia.org/wiki/Eden_District_Municipality, accessed 28 April 2010.

Wikipedia, 2010b. Siyanda District Municipality. http://en.wikipedia.org/wiki/Siyanda_District_Municipality, accessed 28 April 2010.

World Bank, 2003. Building safer cities: The future of disaster risk. Disaster Risk Management Series, No. 3. The International Bank for Reconstruction and Development. 
World Bank, Washington DC.

World Bank, 2006. Natural disaster hotspots: Case studies. Disaster Risk Management Series, No. 6. The World Bank Hazard Management Unit. World Bank, Washington DC. 